University of Nebraska - Lincoln

DigitalCommons@University of Nebraska - Lincoln

Publications from USDA-ARS / UNL Faculty

U.S. Department of Agriculture: Agricultural

Research Service, Lincoln, Nebraska

2009

\title{
Enzymatic Quantification of Phytate in Animal Manure
}

\author{
Zhongqi He \\ United States Department of Agriculture-Agricultural Research Service, Zhongqi.He@ars.usda.gov \\ Heidi W. Waldrip \\ United States Department of Agriculture-Agricultural Research Service \\ C. Wayne Honeycutt \\ United States Department of Agriculture-Agricultural Research Service \\ M. Susan Erich \\ University of Maine \\ Zachary N. Senwo \\ Alabama A\&M University
}

Follow this and additional works at: https://digitalcommons.unl.edu/usdaarsfacpub

Part of the Agricultural Science Commons

He, Zhongqi; Waldrip, Heidi W.; Honeycutt, C. Wayne; Erich, M. Susan; and Senwo, Zachary N., "Enzymatic Quantification of Phytate in Animal Manure" (2009). Publications from USDA-ARS / UNL Faculty. 538. https://digitalcommons.unl.edu/usdaarsfacpub/538

This Article is brought to you for free and open access by the U.S. Department of Agriculture: Agricultural Research Service, Lincoln, Nebraska at DigitalCommons@University of Nebraska - Lincoln. It has been accepted for inclusion in Publications from USDA-ARS / UNL Faculty by an authorized administrator of DigitalCommons@University of Nebraska - Lincoln. 
Communications in Soil Science and Plant Analysis, 40: 566-575, 2009

Copyright (C) Taylor \& Francis Group, LLC

ISSN 0010-3624 print/1532-2416 online

DOI: $10.1080 / 00103620802647116$

\title{
Enzymatic Quantification of Phytate in Animal Manure
}

\author{
Zhongqi He, ${ }^{1}$ Heidi W. Waldrip, ${ }^{1}$ C. Wayne Honeycutt, ${ }^{1}$ M. Susan Erich, ${ }^{2}$ \\ and Zachary N. Senwo ${ }^{3}$ \\ ${ }^{1}$ U.S. Department of Agriculture-Agricultural Research Service, New England \\ Plant, Soil, and Water Laboratory, Orono, Maine, USA \\ ${ }^{2}$ Department of Plant, Soil, and Environmental Sciences, University of Maine, \\ Orono, Maine, USA \\ ${ }^{3}$ Department of Plant and Soil Sciences, Alabama A\&M University, Normal, \\ Alabama, USA
}

\begin{abstract}
Phytate (inositol hexaphosphate) has been identified as a major organic phosphorus (P) form in soil, animal manure, and other environmental samples. Although a number of methods are available for quantitative isolation and determination of phytate, they are time-consuming and not amenable to routine analysis. We developed a simple, rapid method for enzymatic determination of phytate in animal manure. Animal manure was extracted by $\mathrm{H}_{2} \mathrm{O}, 1 \mathrm{M}$ hydrochloric acid $(\mathrm{HCl}), 0.1 \mathrm{M}$ sodium acetate $(\mathrm{NaOAc}, \mathrm{pH} 5.0)$ with or without $0.05 \mathrm{M}$ ethylenediaminetetraacetate (EDTA), and $0.25 \mathrm{M}$ or $0.5 \mathrm{M}$ sodium hydroxide $(\mathrm{NaOH})-0.05 \mathrm{M}$ EDTA. Extracts were diluted $(1 / 10-1 / 150)$ and adjusted to $\mathrm{pH} 5.0$ in sodium acetate buffer. The diluted extracts were then incubated at $37{ }^{\circ} \mathrm{C}$ for $1 \mathrm{~h}$ in the absence and presence of fungal 3-phytase (PHY) and potato acid phosphatase (PAP). Enzymatic hydrolyzable organic P was calculated as the difference in inorganic $\mathrm{P}\left(\mathrm{P}_{\mathrm{i}}\right)$ between the mixtures with and without enzymes. Our data indicated that enzymatic incubation of properly diluted and $\mathrm{pH}$-adjusted $\mathrm{HCl}$ or $\mathrm{NaOH} / \mathrm{EDTA}$ extracts released phytate $\mathrm{P}$. The
\end{abstract}

Trade or manufacturers' names mentioned in the article are for information only and do not constitute endorsement, recommendation, or exclusion by the USDA-ARS.

Address correspondence to Zhongqi He, U.S. Department of AgricultureAgricultural Research Service, New England Plant, Soil, and Water Laboratory, Orono, ME 04469. E-mail: Zhongqi.He@ars.usda.gov 
complementary substrate specificity of the two enzymes is considered to enhance the effectiveness of enzymatic hydrolysis. Consequently, we recommend this method of combining PAP and PHY for quantifying phytate P. Additional research is being conducted to verify the effectiveness of this method for general use across a wider range of soils and manures.

Keywords: Poultry manure, dairy manure, phytic acid, phosphorus

\section{INTRODUCTION}

Phytate or phytic acid (inositol hexaphosphoric acid, IP6) contains a sixcarbon ring with one hydrogen and one phosphate attached to each carbon. Phytate is an important phosphorus (P) storage pool in crop seeds and fruits as the amount of $\mathrm{P}$ in phytate is equal to nearly $65 \%$ of the elemental $\mathrm{P}$ sold worldwide used in mineral fertilizers (Lott et al. 2000). Monogastric animals, such as poultry and swine, lack the ability to digest phytate, leaving significant amounts of phytate as the major organic P form in their excreta (Caldwell and Black 1958; He et al. 2007, He and Honeycutt 2001; He et al. 2006a, 2006b; Turner 2004; Turner and Leytem 2004). Application of low-phytate grains (Bowen et al. 2006; Guttieri, Peterson, and Souza 2006; Raboy et al. 2000) and supplementation with phytase enzymes (Maguire et al. 2004; Park, Choi, and Oh 1999) are two strategies to improve dietary availability of $P$ in animal feedstuffs; however, these practices can result in more unpredictable phytate concentrations in animal manure and thus in the environment. A reliable and convenient analytical method is needed to identify and quantify phytate in animal manure.

High-performance liquid chromatography (HPLC) has been used for analysis of phytate and other inositol phosphates (Woodcock 1997). Because these compounds do not have a characteristic absorption spectrum, their detection by HPLC is limited to methods that monitor refractive index, post-column reaction products, conductivity, or other indirect detection techniques (Woodcock 1997; Xu, Price, and Aggett 1992). Because of this limitation, HPLC is mainly used for "clean" samples in food and biological studies. For animal manure, a traditional analytical method involves hydrochloric acid $(\mathrm{HCl})(0.5 \mathrm{M}$ or greater) extraction and anion-exchange chromatographic separation (Caldwell and Black 1958). Novel methods for the quantitative isolation and determination of phytate include enzymatic hydrolysis coupled with sequential fractionation (He, Griffin, and Honeycutt 2004; He et al. 2006b) and solution P-31 nuclear magnetic resonance (NMR) spectroscopy following sodium hydroxide $(\mathrm{NaOH})$-ethylenediaminetetraacetate (EDTA) extraction (Turner 2004). These methods, however, are 
time-consuming because of multiple-step pretreatments, extraction, or concentration. In this work, we report our effort to develop a simple, rapid enzymatic method for routine analysis of phytate in animal manure.

\section{MATERIALS AND METHODS}

\section{Manure Samples}

A frozen wet poultry manure (PM) from a commercial Maine egg farm (Dail et al. 2007), a dried poultry litter (PL) from a broiler house in Alabama (He et al. 2006b), and a frozen wet dairy manure (DM) from a New York dairy farm (He et al. 2006c) were used in this study. Selected properties of the three samples are listed in Table 1.

\section{Extraction}

Two grams of wet manure samples or $0.3 \mathrm{~g}$ of dry litter sample were suspended in $25 \mathrm{~mL}$ of extractant. Extraction was performed at $22{ }^{\circ} \mathrm{C}$ by placing the sample tubes horizontally on the platform of an orbital shaker $\left(250 \mathrm{r} \mathrm{min}^{-1}\right)$. After $4 \mathrm{~h}$ of extraction, the samples were centrifuged at $12,000 \times \mathrm{g}$ for $20 \mathrm{~min}$. The supernatants were then carefully decanted and filtered through a $0.45-\mu \mathrm{m}$ membrane to obtain the extracts. The extraction was performed in triplicate with six extractants, $\mathrm{H}_{2} \mathrm{O}, 100 \mathrm{mM}$

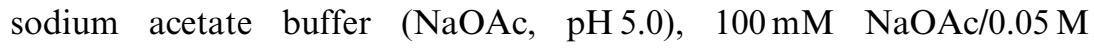
disodium EDTA, $1.0 \mathrm{M} \mathrm{HCl}, 0.25 \mathrm{M} \mathrm{NaOH} / 0.05 \mathrm{M}$ EDTA, or $0.50 \mathrm{M}$ $\mathrm{NaOH} / 0.05 \mathrm{M}$ EDTA. In $1 \mathrm{~mL}$ of each extract, an appropriate amount of $400 \mathrm{mM}$ unbuffered sodium acetate or $2.5 \mathrm{M}$ acetic acid was added with $\mathrm{H}_{2} \mathrm{O}$ and/or $100 \mathrm{mM} \mathrm{NaOAc}$ buffer to a final volume of $10 \mathrm{~mL}$ and pH 5.0.

Table 1. Characteristics of animal manures used in this study

\begin{tabular}{lccccccc}
\hline Sample & $\begin{array}{c}\text { Solid } \\
(\%)\end{array}$ & $\begin{array}{c}\mathrm{P} \\
\left(\mathrm{g} \mathrm{kg}^{-1}\right. \\
\text { dry } \\
\text { matter })\end{array}$ & $\begin{array}{c}\mathrm{Fe} \\
\left(\mathrm{g} \mathrm{kg}^{-1}\right. \\
\text { dry } \\
\text { matter })\end{array}$ & $\begin{array}{c}\mathrm{Al} \\
\left(\mathrm{g} \mathrm{kg}^{-1}\right. \\
\text { dry } \\
\text { matter })\end{array}$ & $\begin{array}{c}\mathrm{Ca} \\
\left(\mathrm{g} \mathrm{kg}^{-1}\right. \\
\text { dry } \\
\text { matter })\end{array}$ & $\begin{array}{c}\mathrm{Mg} \\
\left(\mathrm{g} \mathrm{kg}^{-1}\right. \\
\mathrm{dry} \\
\text { matter })\end{array}$ & $\begin{array}{c}\mathrm{C} \\
\left(\mathrm{g} \mathrm{kg}^{-1}\right. \\
\text { dry } \\
\text { matter })\end{array}$ \\
\hline $\mathrm{PM}$ & 33.2 & 13.9 & 1.14 & 0.53 & 153 & 6.89 & 335 \\
$\mathrm{PL}$ & $\mathrm{N}^{a} \mathrm{~A}^{a}$ & 24.6 & 1.08 & 1.2 & 33.0 & 7.2 & 325 \\
$\mathrm{DM}$ & 14.3 & 6.9 & 0.66 & 0.40 & 16.7 & 6.4 & 521 \\
\hline
\end{tabular}

\footnotetext{
${ }^{a}$ No data available.
} 


\section{Enzymes and Enzymatic Incubation}

Acid phosphatase (EC 3.1.3.2) type IV-S from potato (PAP) and phytase (EC 3.1.3.8) from Aspergillus ficuum (PHY) were purchased from Sigma (St. Louis, Mo.). One unit (U) of enzyme activity was defined as liberation of $1.0 \mu \mathrm{M}$ of relevant product from appropriate substrates at appropriate incubation conditions based on the supplier's information. The stock solutions of acid phosphatase and phytase were then dispensed as $1-\mathrm{mL}$ aliquots into microcentrifuge tubes and stored at $-20{ }^{\circ} \mathrm{C}$ until use.

For enzymatic hydrolysis, the diluted and $\mathrm{pH}$-adjusted extracts were further diluted 4- to 15-fold with distilled water or $\mathrm{NaOAc}$ buffer to maintain a final sodium acetate buffer concentration of $100 \mathrm{mM}, \mathrm{pH} 5.0$. All enzymatic incubations were carried out at $37{ }^{\circ} \mathrm{C}$ for $1-4 \mathrm{~h}$ in a refrigerator-shaker $(250 \mathrm{rpm})$. Each incubation mixture (4 or $5 \mathrm{~mL}$ ) contained potato phosphatase and/or fungal phytase, separately or in combination $\left(0.25 \mathrm{U} \mathrm{mL}^{-1}\right.$ each). Controls were also included where either the enzyme or substrates were omitted.

\section{Phosphorus Determination}

Soluble inorganic orthophosphate $\left(\mathrm{P}_{\mathrm{i}}\right)$ in the incubation mixtures $(0.1-$ $0.2 \mathrm{~mL}$ each) was directly quantified by a molybdate blue method (He and Honeycutt 2005). The $\mathrm{P}_{\mathrm{i}}$ concentration in control samples was designated as inorganic P. Enzymatically hydrolyzable organic $\mathrm{P}$ was calculated as the increase in $\mathrm{P}_{\mathrm{i}}$ concentration after enzymatic incubation. Total $\mathrm{P}$ in each fraction was determined after persulfate-sulfuric acid digestion (He et al. 2006a).

\section{RESULTS AND DISCUSSION}

\section{Recovery of $\mathbf{P}$ with Different Extractants}

Water extracted $4,828 \mathrm{mg} \mathrm{P} \mathrm{kg}^{-1}$ of dry matter in $\mathrm{PM}, 3,213 \mathrm{mg} \mathrm{P} \mathrm{kg}^{-1}$ of dry matter in PL, and $4,280 \mathrm{mg} \mathrm{Pkg}^{-1}$ of dry matter in DM, which accounted for $34.8 \%, 13.1 \%$, and $62.1 \%$ of total $\mathrm{P}$ in the three manure samples, respectively (Table 2). It seems that the higher the total $\mathrm{P}$ content in a manure, the less $\mathrm{P}$ was extracted by water. Extraction with $100 \mathrm{mM}$ NaOAc buffer ( $\mathrm{pH}$ 5.0) effectively improved the recovery of $\mathrm{P}$ from manure. Phosphorus extracted with NaOAc was $55.4 \%$ of total $\mathrm{P}$ for PM, 53.1\% for PL, and $96.9 \%$ for DM. Inclusion of EDTA in $\mathrm{NaOAc}$ buffer further raised the recovery of $\mathrm{P}$ to $95.4 \%$ of total $\mathrm{P}$ in $\mathrm{PM}$ 
Table 2. Recovery of $\mathrm{P}$ in animal manure with different extractants

\begin{tabular}{ccccccc}
\hline Sample & $\mathrm{H}_{2} \mathrm{O}$ & $100 \mathrm{mM}$ & $100 \mathrm{mM}$ & $1.0 \mathrm{M} \mathrm{HCl}$ & $0.25 \mathrm{M}$ & $0.50 \mathrm{M}$ \\
& & $\mathrm{NaOAc}$, & $\mathrm{NaOAc}$, & & $\mathrm{NaOH}$, & $\mathrm{NaOH}$, \\
& & $\mathrm{pH} 5.0$ & $50 \mathrm{mM}$ EDTA, & & $50 \mathrm{mM}$ & $50 \mathrm{mM}$ \\
& & $\mathrm{pH} 5.0$ & & EDTA & EDTA \\
\hline Poultry & $4828 \pm 84^{a}$ & $7687 \pm 334$ & $13250 \pm 611$ & $14518 \pm 708$ & $13458 \pm 310$ & $14318 \pm 557$ \\
manure & $(34.8 \%)$ & $(55.4 \%)$ & $(95.4 \%)$ & $(104.5 \%)$ & $(96.9 \%)$ & $(101.8 \%)$ \\
Poultry & $3213 \pm 155$ & $13053 \pm 1576$ & $15487 \pm 550$ & $15126 \pm 844$ & $15682 \pm 877$ & $15679 \pm 880$ \\
litter & $(13.1 \%)$ & $(53.1 \%)$ & $(63.0 \%)$ & $(61.5 \%)$ & $(63.7 \%)$ & $(63.7 \%)$ \\
Dairy & $4280 \pm 769$ & $6671 \pm 1244$ & $6490 \pm 503$ & $5258 \pm 1182$ & $6706 \pm 314$ & $6322 \pm 503$ \\
manure & $(62.1 \%)$ & $(96.9 \%)$ & $(94.2 \%)$ & $(76.3 \%)$ & $(97.4 \%)$ & $(91.8 \%)$ \\
\hline
\end{tabular}

${ }^{a}$ Mean \pm standard deviation $(\mathrm{n}=3)$ in $\mathrm{mg} \mathrm{kg}^{-1}$ of dry matter. Values in parenthesis are the $\%$ of total $\mathrm{P}$ extracted from each sample.

and to $63.0 \%$ of total P in PL. Turner (2004) found that inclusion of $0.05 \mathrm{M}$ EDTA in $0.25 \mathrm{M} \mathrm{NaOH}$ raised the recovery of $\mathrm{P}$ from three manures from $32-53 \%$ to $80-96 \%$. In this study, there was no further improvement in $\mathrm{P}$ extraction with either 0.25 or $0.50 \mathrm{M} \mathrm{NaOH}$ with EDTA, as compared with the recovery of $\mathrm{P}$ by NaOAc with EDTA (Table 2). Combining this work with the findings of Turner (2004), it seems that EDTA is more critical than $\mathrm{NaOAc}$ or $\mathrm{NaOH}$ in improving the extraction efficiency.

Hydrochloric acid (1.0 M) also extracted $\mathrm{P}$ in PM and PL as effectively as sodium acetate and $\mathrm{NaOH}$ with $50 \mathrm{mM}$ EDTA. However, only $76.3 \%$ of $\mathrm{P}$ was extracted from $\mathrm{DM}$ by $1.0 \mathrm{M} \mathrm{HCl}$, lower than the recovery of DM P by $\mathrm{NaOAc}$ and $\mathrm{NaOH}$. Previously, Turner (2004) reported that $1.0 \mathrm{M} \mathrm{HCl}$ extracted less $\mathrm{P}$ from cattle and swine manures than $\mathrm{NaOH} /$ EDTA, whereas both extractants recovered equal amounts of $\mathrm{P}$ from boiler litter; therefore, $\mathrm{NaOH}$ or $\mathrm{NaOAc}$ with EDTA both appear superior to $\mathrm{HCl}$ for extracting manure $\mathrm{P}$.

\section{Enzymatic Release of Organic P}

Enzymatic incubation slightly increased $\mathrm{P}_{\mathrm{i}}$ concentrations by 1,5 , and $5 \%$ for PAP, PHY, and PAP + PHY, respectively, in $\mathrm{H}_{2} \mathrm{O}$ extracts, and 1,8 , and $8 \%$ in $\mathrm{NaOAc}$ extracts of PM (Figure 1). Based on the substrate specificity of the two enzymes (He et al. 2007; He, Griffin, and Honeycutt 2004), these data indicate there were only negligible amounts of easily soluble simple monoester $\mathrm{P}$ and small amounts of easily soluble phytate in the layer hen manure. Enzymatic hydrolysis markedly increased $\mathrm{P}_{\mathrm{i}}$ concentrations in $\mathrm{NaOAc/EDTA}, \mathrm{HCl}$, and $\mathrm{NaOH} / \mathrm{EDTA}$ extracts. The increases in $\mathrm{P}_{\mathrm{i}}$ were in the ranges of $7-15,24-37$, and $37-38 \%$ for PAP, PHY, and PAP + PHY, respectively (Figure 1). There was no difference in $\mathrm{P}$ released by $\mathrm{PHY}$ and the combination of PAP $+\mathrm{PHY}$ except in the 


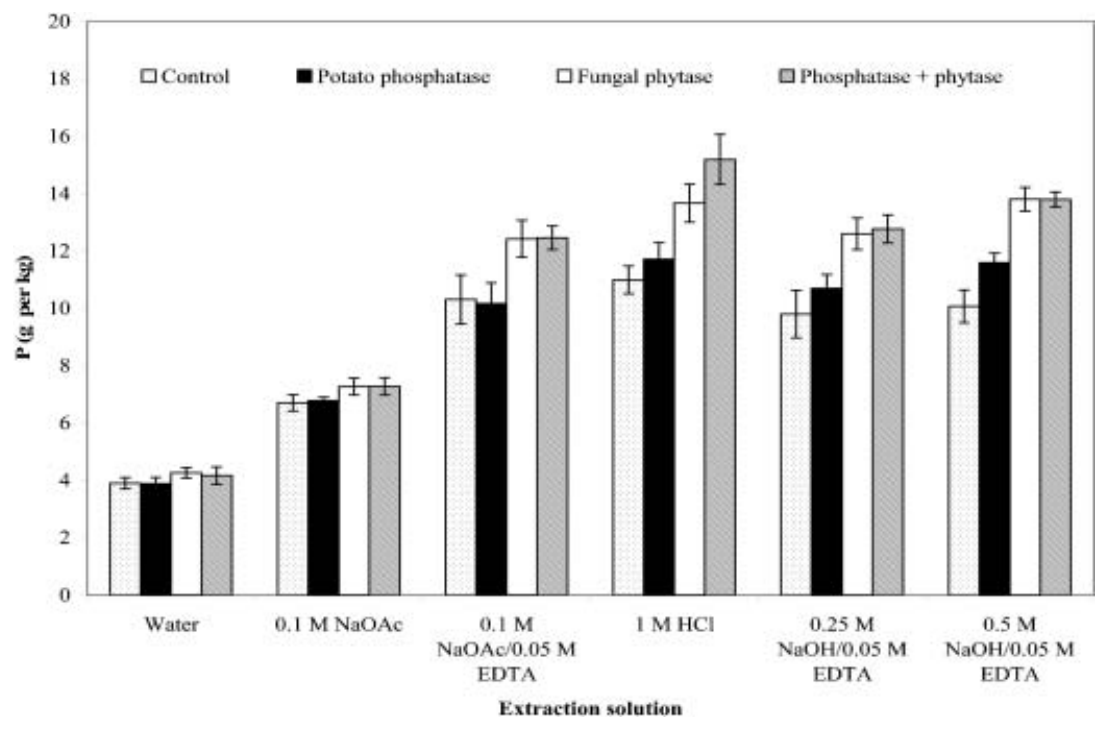

Figure 1. Enzymatic release of organic $\mathrm{P}$ in poultry manure.

$\mathrm{HCl}$ extract. This difference is to be expected, as phytate $\mathrm{P}$ is the major organic $\mathrm{P}$ in animal manure (He et al. 2007). Further incubation up to $24 \mathrm{~h}$ did not increase $P_{i}$ detected in these reaction mixtures (data not shown).

Similar results were observed in the water extracts of PL (Figure 2). Only small amounts of $\mathrm{P}$ were water extractable, and very little extractable $\mathrm{P}$ was organic. Unlike results observed in PM, PHY and $\mathrm{PAP}+\mathrm{PHY}$ released a large amount of organic $\mathrm{P}$ in the NaOAc extract, increasing the $P_{i}$ detected by $170 \%$ to $190 \%$. The amounts of $P_{i}$ detected in the other four extracts were quite consistent: incubation of the four extracts with PHY and PAP + PHY increased $\mathrm{P}_{\mathrm{i}}$ in solution by approximately $300 \%$.

Enzymatic incubation also released organic $\mathrm{P}$ in DM extracts (Figure 3). The highest increase in $P_{i}$ was still observed in the incubation with PAP + PHY. However, the observed increase was much lower than that of PL. PAP $+\mathrm{PHY}$ increased $\mathrm{P}_{\mathrm{i}}$ in $\mathrm{HCl}$ extracts of $\mathrm{DM}$ by $50 \%$, but just 10 to $29 \%$ in other extracts as compared to the DM control. Incubation with PAP increased $\mathrm{P}_{\mathrm{i}}$ in all the extracts to a larger extent in $\mathrm{DM}$ than in PM and PL. For instance, the increase in $\mathrm{P}_{\mathrm{i}}$ due to PAP hydrolysis was $12 \%$ in $0.1 \mathrm{M} \mathrm{NaOAc}$ extract and $11 \%$ in $0.25 \mathrm{M} \mathrm{NaOH} /$ $0.05 \mathrm{M}$ EDTA. Data in Figures 1-3 show that the combination of PAP and PHY consistently released equal or higher amounts of organic $\mathrm{P}$ than either enzyme alone from all extract and manure combinations. This is due to the complementary substrate specificity of the two enzymes, which 


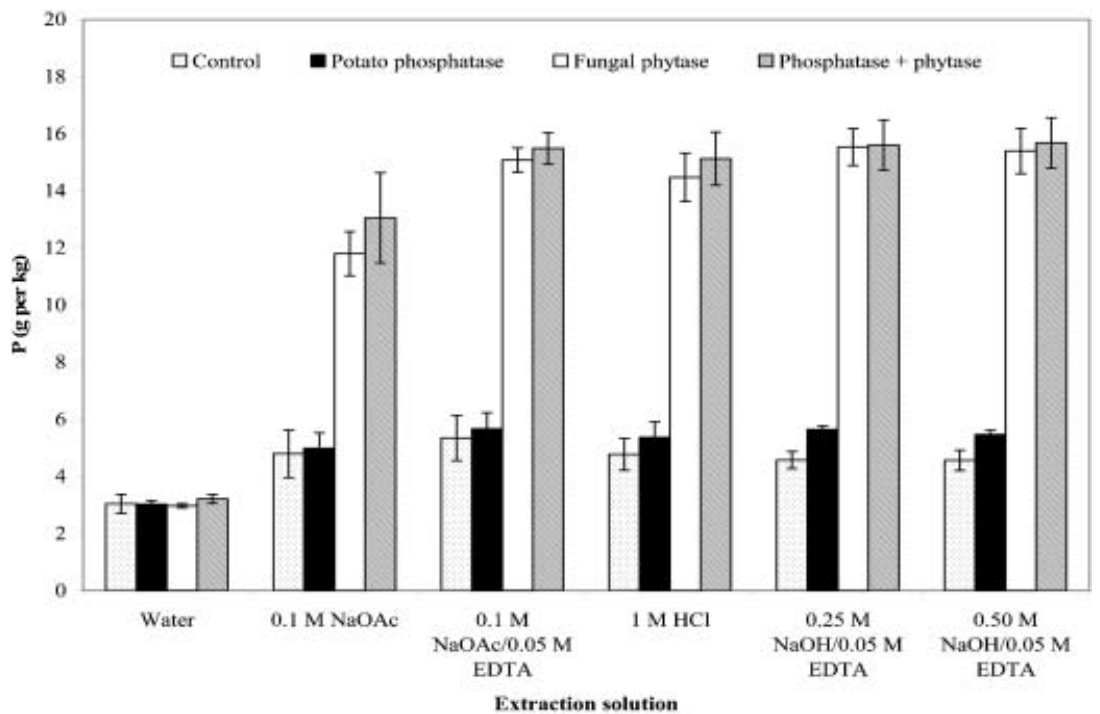

Figure 2. Enzymatic release of organic $\mathrm{P}$ in poultry litter.

enhances the effectiveness of enzymatic hydrolysis (He et al. 2007; He, Griffin, and Honeycutt 2004). We therefore recommend this method of combining PAP and PHY for quantifying phytate P.

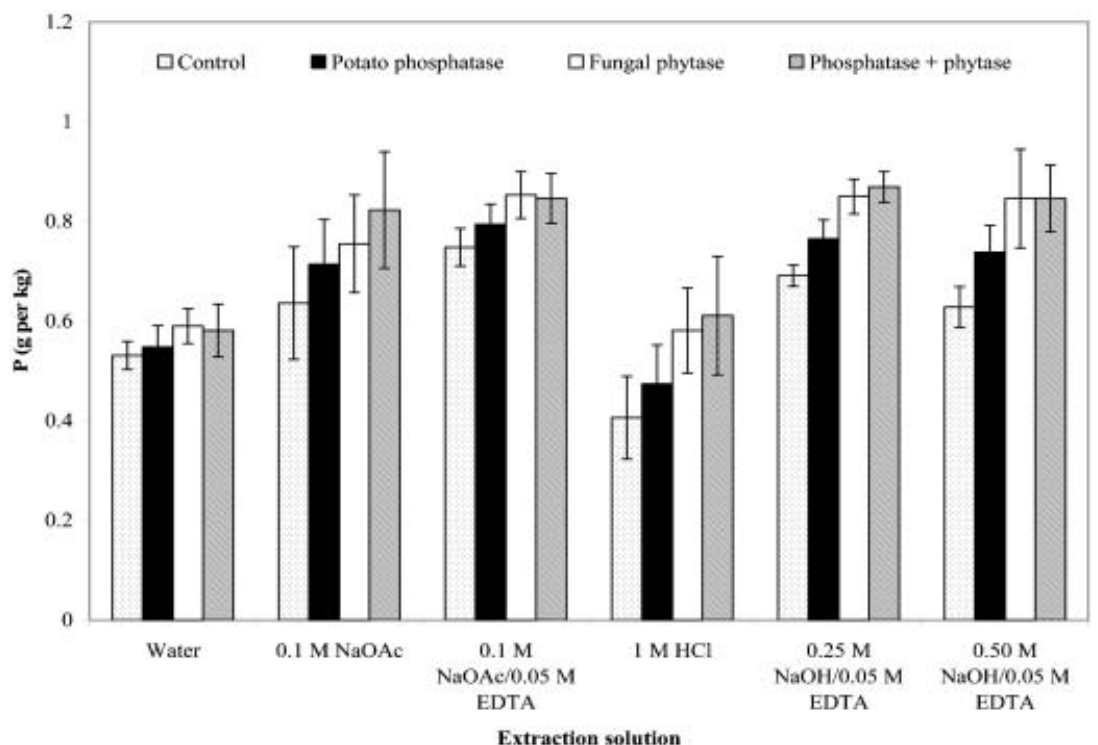

Figure 3. Enzymatic release of organic $\mathrm{P}$ in dairy manure. 
With the procedure described in the materials and methods section, we could assign three types of $\mathrm{P}$ in the three manures: inorganic $\mathrm{P}\left(\mathrm{P}_{\mathrm{i}}\right.$ determined in control), simple monoester $\mathrm{P}\left(\mathrm{P}_{\mathrm{i}}\right.$ increased after incubation with PAP), and phytate $\mathrm{P}$ (difference in $\mathrm{P}_{\mathrm{i}}$ after incubation with PAP + PHY compared to PAP alone). The composition of the three $\mathrm{P}$ types changed greatly with type of extractants used in these three manure samples (Table 3). In a trend similar to the results for total $\mathrm{P}$, the concentration of the three $\mathrm{P}$ forms increased in the order of $\mathrm{H}_{2} \mathrm{O}<$ $\mathrm{NaOAc}(\mathrm{pH} 5.0)<\mathrm{NaOAc} /$ EDTA $\approx 0.25 \mathrm{M}$ or $0.5 \mathrm{M} \mathrm{NaOH} / \mathrm{EDTA} \approx$ $\mathrm{HCl}$ and was consistent with the extractant power of these solutions. In fact, the concentrations of phytate determined in the extracts of $\mathrm{NaOAc}$ and $\mathrm{NaOH}$ with EDTA were not statistically significantly different for $\mathrm{PM}$ and PL (Table 3). Interestingly, even though, compared to $\mathrm{NaOAc}$ and $\mathrm{NaOH}, 1.0 \mathrm{M} \mathrm{HCl}$ extracted relatively less total $\mathrm{P}$ from DM, the level of phytate in the $\mathrm{HCl}$ extract was high. The difference was due to lower levels of inorganic $\mathrm{P}$ extracted by $\mathrm{HCl}$. This observation implies that previous methods using $\mathrm{HCl}$ for extracting phytate $\mathrm{P}$ in animal manure (Caldwell and Black 1958) are still valid even though total P may not always be fully recovered.

Phytate $\mathrm{P}$ was the major $\mathrm{P}$ form in PL. Its concentration doubled the inorganic $\mathrm{P}$ concentration in the $63 \%$ of total $\mathrm{P}$ extracted. This is

Table 3. Concentrations $\left(\mathrm{mg} \mathrm{kg}^{-1}\right.$ dry matter) of inorganic $\mathrm{P}\left(\mathrm{P}_{\mathrm{i}}\right)$, simple monoester $\mathrm{P}\left(\mathrm{P}_{\mathrm{sm}}\right)$, and phytate $\mathrm{P}\left(\mathrm{P}_{\mathrm{ip} 6}\right)$ extracted by different extractants

\begin{tabular}{|c|c|c|c|c|c|c|}
\hline Sample & $\mathrm{H}_{2} \mathrm{O}$ & $\begin{array}{c}100 \mathrm{mM} \\
\mathrm{NaOAc}, \\
\text { pH } 5.0\end{array}$ & $\begin{array}{c}100 \mathrm{mM} \\
\mathrm{NaOAc}, \\
50 \mathrm{mM} \\
\text { EDTA, } \\
\text { pH } 5.0\end{array}$ & $\begin{array}{c}1.0 \mathrm{M} \\
\mathrm{HCl}\end{array}$ & $\begin{array}{c}0.25 \mathrm{M} \\
\mathrm{NaOH}, \\
50 \mathrm{mM} \\
\text { EDTA }\end{array}$ & $\begin{array}{c}0.50 \mathrm{M} \\
\mathrm{NaOH}, \\
50 \mathrm{mM} \\
\text { EDTA }\end{array}$ \\
\hline \multicolumn{7}{|l|}{ Poultry manure } \\
\hline $\mathrm{P}_{\mathrm{i}}\left(\mathrm{mg} \mathrm{kg}^{-1}\right)$ & $3900 \mathrm{a}^{a}$ & $6705 b$ & $10307 \mathrm{c}$ & $10992 \mathrm{c}$ & $9799 \mathrm{c}$ & $10067 \mathrm{c}$ \\
\hline $\mathrm{P}_{\mathrm{sm}}\left(\mathrm{mg} \mathrm{kg}^{-1}\right)$ & $0 \mathrm{a}$ & $115 \mathrm{ab}$ & $61 \mathrm{a}$ & $725 b$ & $895 \mathrm{bc}$ & $1522 d$ \\
\hline $\mathrm{P}_{\mathrm{ip} 6}\left(\mathrm{mg} \mathrm{kg}^{-1}\right)$ & $218 \mathrm{a}$ & $458 \mathrm{a}$ & $2092 b$ & $3484 \mathrm{c}$ & $2075 b$ & $2205 b$ \\
\hline \multicolumn{7}{|l|}{ Poultry litter } \\
\hline$P_{i}\left(\mathrm{mg} \mathrm{kg}^{-1}\right)$ & $3043 a$ & $4795 b$ & $5346 b$ & $4775 b$ & $4525 b$ & $4565 b$ \\
\hline $\mathrm{P}_{\mathrm{sm}}\left(\mathrm{mg} \mathrm{kg}^{-1}\right)$ & $100 \mathrm{a}$ & $230 \mathrm{a}$ & $340 \mathrm{a}$ & $590 \mathrm{a}$ & $1122 b$ & $901 b$ \\
\hline$P_{\mathrm{ip} 6}\left(\mathrm{mg} \mathrm{kg}^{-1}\right)$ & $70 \mathrm{a}$ & $8028 b$ & $9800 \mathrm{~b}$ & $9120 b$ & $9963 b$ & $10190 \mathrm{~b}$ \\
\hline \multicolumn{7}{|l|}{ Dairy manure } \\
\hline $\mathrm{P}_{\mathrm{i}}\left(\mathrm{mg} \mathrm{kg}^{-1}\right)$ & $3715 \mathrm{a}$ & $4448 \mathrm{a}$ & $5230 \mathrm{~b}$ & $2836 \mathrm{a}$ & $4827 \mathrm{c}$ & $4386 \mathrm{c}$ \\
\hline $\mathrm{P}_{\mathrm{sm}}\left(\mathrm{mg} \mathrm{kg}^{-1}\right)$ & $126 a$ & $544 a b$ & $319 b c$ & $471 b c$ & $522 \mathrm{bd}$ & $771 \mathrm{bd}$ \\
\hline$P_{\text {ip6 }}\left(\mathrm{mg} \mathrm{kg}^{-1}\right)$ & $291 \mathrm{a}$ & $767 \mathrm{a}$ & $389 a$ & $965 b$ & $723 b$ & $858 b$ \\
\hline
\end{tabular}

${ }^{a}$ Concentrations followed by the same letter within rows are not significantly different $(\alpha=0.05)$. 
consistent with the previous observation (He et al. 2006b). The concentrations of phytate $\mathrm{P}$ in DM were relatively low with more simple monoester P present. That is, near one third to one half of hydrolyzable organic $\mathrm{P}$ was simple monoester P. Based on these data, for practical application of this method, a control and a combination of PAP and PHY could be used to determine the phytate $\mathrm{P}$ concentration in extracts of animal manure. Incubation with PAP is recommended for more accurate determination or in distinguishing phytate $\mathrm{P}$ from other simple monoester P.

\section{CONCLUSIONS}

Enzymatic incubation of properly diluted and $\mathrm{pH}$-adjusted $\mathrm{NaOAc}$ or $\mathrm{NaOH} / \mathrm{EDTA}$ extracts released organic $\mathrm{P}$ in animal manure. The complementary substrate specificity of potato acid phosphatase (PAP) and fungal phytase (PHY) enhanced the effectiveness of enzymatic hydrolysis; consequently, we recommend this method of combining PAP and PHY for quantifying phytate P. An additional incubation with PAP alone should be included for distinguishing other simple monoester $P$ from phytate $\mathrm{P}$ if needed. Additional research is being conducted to verify the general use of this method across a wider range of soils and manures.

\section{REFERENCES}

Bowen, D. E., M. J. Guttieri, K. Peterson, K. Peterson, V. Raboy, and E. J. Souza. 2006. Phosphorus fractions in developing seeds of four low phytate barley (Hordeum vulgare L.) genotypes. Crop Sci. 46:2468-2473.

Caldwell, A. G., and C. A. Black. 1958. Inositol hexaphosphate, I: Quantitative determination in extracts of soils and manures. Soil Sci. Soc. Amer. Proc. 22:290-293.

Dail, H. W., Z. He, M. S. Erich, and C. W. Honeycutt. 2007. Effect of drying on phosphorus distribution in poultry manure. Commun. Soil Sci. Plant Anal. 38:1879-1895.

Guttieri, M. J., K. M. Peterson, and E. J. Souza. 2006. Agronomic performance of low phytic acid wheat. Crop Sci. 46:2623-2629.

He, Z., B. J. Cade-Menun, G. S. Toor, A. Fortuna, C. W. Honeycutt, and J. T. Sims. 2007. Comparison of phosphorus forms in wet and dried animal manures by solution phosphorus-31 nuclear magnetic resonance spectroscopy and enzymatic hydrolysis. J. Environ. Qual. 36:1086-1095.

He, Z., A. Fortuna, Z. N. Senwo, I. A. Tazisong, C. W. Honeycutt, and T. S. Griffin. 2006a. Hydrochloric fractions in Hedley fractionation may contain inorganic and organic phosphates. Soil Sci. Soc. Am. J. 70:893-899.

He, Z., T. S. Griffin, and C. W. Honeycutt. 2004. Enzymatic hydrolysis of organic phosphorus in swine manure and soil. J. Environ. Qual. 33:367-372. 
He, Z., and C. W. Honeycutt. 2001. Enzymatic characterization of organic phosphorus in animal manure. J. Environ. Qual. 30:1685-1692.

He, Z., and C. W. Honeycutt. 2005. A modified molybdate blue method for orthophosphate determination suitable for investigating enzymatic hydrolysis of organic phosphates. Commun. Soil Sci. Plant Anal. 36:1373-1383.

He, Z., Z. N. Senwo, R. N. Mankolo, and C. W. Honeycutt. 2006b. Phosphorus fractions in poultry litter characterized by sequential fractionation coupled with phosphatase hydrolysis. J. Food Agri. Environ. 4:304-312.

He, Z., G. S. Toor, C. W. Honeycutt, and J. T. Sims. 2006c. An enzymatic hydrolysis approach for characterizing labile phosphorus forms in dairy manure under mild assay conditions. Bioresour. Technol. 97:1660-1668.

Lott, J. N. A., I. Ockenden, V. Raboy, and G. D. Batten. 2000. Phytic acid and phosphorus in crop seeds and fruits: Global estimate. Seed Sci. Res. 10:11-33.

Maguire, R. O., J. T. Sims, W. W. Saylor, B. L. Turner, R. Angel, and T. J. Applegate. 2004. Influence of phytase addition to poultry diets on phosphorus forms and solubility in litters and amended soils. J. Environ. Qual. 33:23062316.

Park, S. C., Y. W. Choi, and T. K. Oh. 1999. Comparative enzymatic hydrolysis of phytate in various animal feedstuff with two different phytases. J. Vet. Med. Sci. 61:1257-1259.

Raboy, V., P. F. Gerbasi, K. A. Young, S. D. Stoneberg, S. G. Pickett, A. T. Bauman, P. P. N. Murthy, W. F. Sheridan, and D. S. Ertl. 2000. Origin and seed phenotype of maize low phytic acid 1-1 and low phytic acid 2-1. Plant Physiol. 124:355-368.

Turner, B. L. 2004. Optimizing phosphorus characterization in animal manures by solution phosphorus-31 nuclear magnetic resonance spectroscopy. $J$. Environ. Qual. 33:757-766.

Turner, B. L., and A. B. Leytem. 2004. Phosphorus compounds in sequential extracts of animal manure: Chemical speciation and a novel fractionation procedure. Environ. Sci. Technol. 38:6101-6108.

Woodcock, E. A. 1997. Analysis of inositol phosphates in heart tissue using anion-exchange high-performance liquid chromatography. Mol. Cell Biochem. 172:121-127.

Xu, P., J. Price, and P. J. Aggett. 1992. Recent advances in methodology for analysis of phytate and inositol phosphates in foods. Prog. Food Nutr. Sci. $16: 245-262$. 